\title{
Humeral quality and adrenal responsiveness in laying hens reared in standard and furnished cages
}

\author{
Vanessa GuESDON, Christine LETERRIER, Paul CONSTANTIN, \\ Daniel GuÉMENÉ*, Michel COUTY, Jean Michel FAURE
}

Station de Recherches Avicoles, INRA, Centre de Tours, 37380 Nouzilly, France

(Received 17 July 2003; accepted 2 March 2004)

\begin{abstract}
In order to find out whether furnished cages contribute to improving the welfare of laying hens, humerus quality and adrenal responsiveness were evaluated in laying hens reared in standard (S) and furnished cages (F). Four cage models were used: S5, a standard cage model with 5 hens per cage; S6, a standard cage model with 6 hens per cage; F7, a furnished cage model with 7 hens per cage (with a nest, dust-bathing box, two perches, and claw-shortening) and F15, a furnished cage model with 15 hens per cage (with a nest, dust-bathing box, two perches, and claw-shortening). At 72 weeks of age, maximal adrenal responsiveness was evaluated by measuring the changes in blood corticosterone level induced by the i.m. injection of $10 \mu \mathrm{g}$ per hen of 1-24 ACTH ( $\mathrm{n}=15$ hens per cage model). Hens ( $n=15$ to 23 hens per cage model) were slaughtered and the left and right humeri were used for measurement of weight, biomechanical characteristics in a flexion test, dry matter and ash percentage. Basal corticosterone levels did not differ significantly while the injection of ACTH produced a significant rise in corticosterone levels $(P<0.001)$ of similar amplitude for all cage models. Humeri weights, biomechanical characteristics (elastic strain, bioyield point, stiffness and breaking strength), dry weight and percentage of dry matter were not significantly different between cage models. The humeri ash percentage was significantly $(P=0.03)$ lower in birds from the S6 cage model (57.4\%) than in birds from other cage models (S5: 59.0\%; F7: 58.9\%; F15: 59.7\%). Adrenal responsiveness and major humeral characteristics were not significantly improved in furnished compared to standard cages in our experimental conditions.
\end{abstract}

laying hen / furnished cages / exercise / bone / corticosterone / welfare

Résumé - Qualité de l'os et capacité de réponse de la glande surrénale chez des poules pondeuses élevées en cages standard et en cages aménagées. Afin d'analyser si les dispositifs d'enrichissement apportés dans des cages aménagées contribuent à l'amélioration du bien-être chez la poule pondeuse, nous avons mesuré la réactivité des glandes surrénales et la qualité des humérus de poules pondeuses élevées en cages standard et en cages aménagées. Quatre modèles de cage ont été comparés : une cage standard à 5 poules $S 5$, une cage standard à 6 poules $S 6$, une cage aménagée à 7 poules $F 7$ (avec un nid, un bac à poussière, 2 perchoirs, un système raccoucisseur de griffes) et une cage aménagée à 15 poules $\mathrm{F} 15$ (avec un nid, un bac à poussière, 2 perchoirs, un système raccourcisseur de griffes). La capacité de réponse maximale a été testée en comparant les corticostéronémies mesurées

\footnotetext{
* Corresponding author: guemene@tours.inra.fr
} 
avant et après l'injection i.m. de $10 \mu \mathrm{g}$ par poule d'ACTH $1-24(\mathrm{n}=15$ poules par modèle de cage). Quinze à 23 poules par modèle de cage ont été abattues à l'âge de 72 semaines. Le poids, les caractéristiques biomécaniques et la composition des humérus droit et gauche ont été mesurés. Les taux de bases de la corticostéronémie ne différaient pas significativement tandis que l'injection d'ACTH induisait une augmentation significative de la corticostéronémie $(P<0,001)$ dont l'amplitude était comparable pour chaque modèle de cage. Le poids des humérus, leurs caractéristiques biomécaniques (déformation élastique, résistance élastique, rigidité, résistance à la rupture), leur poids sec et leur pourcentage de matière sèche n'étaient pas significativement différents entre les modèles de cage. Le pourcentage de cendres était significativement $(P=0,03)$ plus faible pour les humérus des oiseaux du modèle de cage S6 $(57,4 \%)$ comparés aux humérus des poules des autres modèles de cage (S5 : $59,0 \% ; \mathrm{F} 7: 58,9 \% ; \mathrm{F} 15: 59,7 \%$ ). La réactivité des glandes surrénales ainsi que les caractéristiques principales des humérus n'ont pas été significativement améliorées dans les cages aménagées par rapport aux cages standard dans nos conditions expérimentales.

\section{poule pondeuse / cage aménagée / exercice / qualité de l'os / corticostérone / bien-être}

\section{INTRODUCTION}

The rearing of laying hens in standard cages has been the focus of discussion for several years, especially since the adoption of the 1999 European Directive [10]. Two main criticisms are addressed to this type of cage: the living space is too small and too uniform. These rearing conditions are reported to have a direct impact on the welfare of laying hens [8, 39]. Such space restriction also limits the possibility of bird movement and consequently appears to be at the origin of weak skeletons [17, 36, 41]. In standard cages, hens are housed in an extremely bare environment, without a nest, litter and perches. Hens therefore cannot fully perform laying, dust-bathing and perching behaviours. This impoverishment of the behavioural repertoire may be at the origin of stress and stereotyped behaviour [5, 16, $34,38,46,47,50]$. It might be possible to improve hen welfare with rearing systems that include a larger living space and an enriched environment. Two new systems have been proposed: aviaries and furnished cages [29]. Aviaries have disadvantages since the mortality rate is increased by cannibalism, and certain sanitary problems are enhanced for the animal and affect eggshell quality $[2,33]$. The furnished cage might be an acceptable compromise between the standard cage and the aviary because it combines several advantages of both systems and minimises the disadvantages.
The aim of adding furniture in the cages is to increase the possibility that hens express their behavioural repertoire. Providing new items allows hens to perform laying behaviour and dust-bathing but it is also believed to increase their possibility of having physical activities. The effect of exercise on bone has been widely documented in human osteoporosis [51] and rats [13] where physical activity increases bone apposition while, on the contrary, a reduction in mechanical stresses by spaceflight decreases bone density [11]. Improvement of bone apposition via exercise has also been reported in chickens [42, 52] and in laying hens [32]. Increasing bone apposition is of particular interest in laying hens since many of them are affected by cage layer osteoporosis which consists of bone loss and is also considered to be the primary cause of bone fractures during processing. In a survey of a commercial flock, McCoy et al. [31] considered that $35 \%$ of deaths were attributable to osteoporosis and death occurred earlier in osteoporotic hens (45.5 weeks of age) than in non-osteoporotic hens (51.6 weeks of age). Giving access to perches has been shown to increase tarsometatarsus bone volume in laying hens [23, 53]. Enrichment with perches, nests and dust baths also increased the maximum strength of the humerus at slaughter in 80-week-old laying hens [3]. However, giving access to perches in cages and systems such as aviaries has sometimes failed to improve tibial breaking strength $[23,48]$. 
Standard cages limit physical activity and, as a boring environment, are also considered to be a source of frustration and consequently a chronically stressful environment $[5,12,16,24,37]$. Activation of the adreno-corticotropic axis in response to acute stress has been demonstrated in birds $[18,35,45]$ indicated by a rise in plasma corticosterone levels in the peripheral circulation in birds $[9,21,26,35]$. On the contrary, chronic stress or repeated acute stress such as repeated handling can lead to a progressive decrease in corticosterone response or fear in various species $[12,14,25]$. One approach to investigating chronic stress consists of using ACTH stimulation [49] to measure adreno-corticotropic responsiveness [18, 28, 30, 45].

The data reported here complement zootechnical data [20] obtained in different cage systems in the context of the laying hen directive [10]. In the present study, we focused on two physiological and welfare indicators, bone quality and adrenal responsiveness. The ACTH stimulation test [19, 49] was used to investigate chronic stress in hens reared in standard and furnished cages. Since the humerus is the bone showing the greatest response to husbandry systems $[17$, $27,36]$, humeral characteristics were measured for morphology, biomechanics and composition in order to investigate bone quality.

\section{MATERIALS AND METHODS}

\subsection{Animals and rearing conditions}

Standard cages (S) and furnished cages (F) were used according to directive 1999/ 74/CE. Two models of each type were used. The maximum of hens was housed in each cage, respecting the different limiting factors according to EU-law such as food trough length per hen, area per hen and so on. The cages differed mainly by the cage design and group sizes (see [20] for details). Four cage models were used: S5 $(n=96)$, a standard cage model with 5 hens per cage (Length $59.5 \mathrm{~cm} \times$ Depth $55.5 \mathrm{~cm} \times$ Height $41.5 \mathrm{~cm}$, no extra-furniture); S6 $(\mathrm{n}=108)$, a standard cage model with 6 hens per cage (L $60 \mathrm{~cm} \times \mathrm{D} 63.5 \mathrm{~cm} \times \mathrm{H} 51 \mathrm{~cm}$, no extrafurniture); F7 ( $=72)$, a furnished cage model with 7 hens per cage (L $91 \mathrm{~cm} \times \mathrm{D}$ $63.5 \mathrm{~cm} \times \mathrm{H} 51 \mathrm{~cm}$, with a nest, dust-bathing box, two perches and claw-shortening) and F15 $(\mathrm{n}=24)$, a furnished cage model with 15 hens per cage ( $\mathrm{L} 233 \mathrm{~cm} \times \mathrm{D} 73 \mathrm{~cm} \times \mathrm{H}$ $54 \mathrm{~cm}$, with a nest, a dust-bathing box, two perches, and claw-shortening). The furnished cages provided two plastic perches across the length of the cage.

At 18 weeks of age, beak trimmed ISABrown hens were housed in standard cages and furnished cages. The lighting schedule was 15 hours light / 9 hours dark and the room temperature was maintained at 20 $22{ }^{\circ} \mathrm{C}$ whenever possible. The hens were fed a standard diet $(\mathrm{EM}=2800 \mathrm{kcal}, \mathrm{CP}=$ $16.3 \%$, Ca $3.6 \%$, available $P=0.3 \%$ ). Food and water were available ad libitum.

\subsection{Adrenal responsiveness}

Sixty laying hens from 60 different cages (15 hens for each specific cage model, one randomly chosen hen per cage) were selected at 72 weeks of age. The hens received a single i.m. injection of $10 \mu \mathrm{g}$ per hen (approximately $5 \mu \mathrm{g} \cdot \mathrm{kg}^{-1} \mathrm{BW}$ ) 1-24 ACTH (Immediate Synacthen, Norvatis, 2 and 4 rue Lionel Terray, BP 308, F-92506 Rueil Malmaison Cedex) diluted in saline solution $(400 \mu \mathrm{L}$, $0.9 \% \mathrm{NaCl} w / v)$. This dose has been shown to induce maximal HPA reactivity $15 \mathrm{~min}$ post injection in both laying hens (unpublished data) and in other bird species (ducks, [40]; turkeys and quails, unpublished data). Blood samples $(3 \mathrm{~mL})$ were collected from the wing vein into heparinised tubes prior to the injection and 15 min post-injection and the hens were placed in a crate during the period between the two samplings.

The plasma was separated by centrifugation, and stored at $-20{ }^{\circ} \mathrm{C}$ before being 
Table I. Corticosterone concentration (ng $\mathrm{ml}^{-1}$ plasma) prior (T0) and after (T15 min) i.m. injection of ACTH ( $10 \mu \mathrm{g}$ per laying hen at 72 weeks of age $)$ in different cage models.

\begin{tabular}{|c|c|c|c|c|c|c|c|c|}
\hline \multirow[b]{3}{*}{ Number of hens } & \multicolumn{4}{|c|}{ Cage models } & \multirow{3}{*}{ SEM } & \multirow{2}{*}{\multicolumn{3}{|c|}{$P$-value ${ }^{1}$}} \\
\hline & \multirow{2}{*}{$\begin{array}{l}\text { S5 } \\
15\end{array}$} & \multirow{2}{*}{$\begin{array}{l}\text { S6 } \\
15\end{array}$} & \multirow{2}{*}{$\begin{array}{l}\text { F7 } \\
15\end{array}$} & \multirow{2}{*}{$\begin{array}{r}\text { F15 } \\
15\end{array}$} & & & & \\
\hline & & & & & & Cage & Time & Cage $\times$ Time \\
\hline T0 & 2.3 & 3.0 & 2.2 & 1.5 & 0.24 & 0.49 & $<0.001$ & 0.25 \\
\hline T15 (min) & 21.6 & 22.5 & 23.9 & 23.5 & 2.01 & & & \\
\hline
\end{tabular}

${ }^{1}$ One ANOVA with repeated measures.

assayed. Plasma corticosterone levels were measured in duplicate using a specific radioimmunoassay [15]. All samples from a specific trial were assayed within the same specific assay. Calculations of the radioimmunoassay were performed using the RIASmart Programme (Packard Instrument Co., Camberra, 1989).

\subsection{Humeral quality}

One randomly chosen hen per cage from 23 furnished cages of each model and 15 standard cages of each model was identified. The marked birds were slaughtered at 72 weeks of age. The right and left humeri bones were removed from the carcasses and were frozen at $-20{ }^{\circ} \mathrm{C}$ until processing. Humeri were weighed when thawed to obtain a hydrated weight.

A three-point flexure test was then carried out on the bones (Instron Number 1102, High Wycombe, UK). The rate of travel of the mobile anvil was $5 \mathrm{~mm}$ per min and the width of the bearer was $45 \mathrm{~mm}$. Stiffness was calculated as the slope of the loading curve before the bioyield point [22], i.e. the inflection point of the loading curve.

The humeri were then defatted in ether for $24 \mathrm{~h}$, dried $\left(110^{\circ} \mathrm{C}\right.$ for $\left.12 \mathrm{~h}\right)$ and weighed. The bones were ashed $\left(550^{\circ} \mathrm{C}\right.$ for $\left.14 \mathrm{~h}\right)$ and ash weight was calculated relative to dry weight in order to obtain the ash percentage.

\subsection{Statistical analysis}

Mean values between left and right humeri were used. Humeral data were compared using one way ANOVA followed by the PLSD Fisher test. Body weight was not introduced as a covariate in the ANOVA since the humeral weights and the mechanical characteristics of the humeri were not correlated with body weight. The introduction of body weight as a covariate did not modify the ANOVA results. Corticosterone concentrations were compared by repeated measures ANOVA.

\section{RESULTS}

The ACTH injection effect $(=$ time effect) was highly significant $(P<0.001)$, whereas the cage model effect $(P=0.49)$ and the interaction $(P=0.25)$ were not. Mean basal levels ranged from 1.5 to $3.0 \mathrm{ng} \cdot \mathrm{ml}^{-1}$ of plasma and the mean responses measured 15 min ACTH post-injection ranged from 21.5 to $24.0 \mathrm{ng} \cdot \mathrm{ml}^{-1}$ of plasma (Tab. I).

The responses of the humeri to the flexion test were not significantly different between the four models during the elastic part of the loading curve (elastic strain, bioyield point, stiffness, Tab. II). The breaking strength was not affected by the cage model effect (Tab. II).

There was no significant cage model effect on the hydrated weight, dry weight of the humeri, nor on the percentage of dry 
Table II. Mean values for humeral biomechanical parameters in the 72 week-old laying hen in different cage models.

\begin{tabular}{lcccccc}
\hline & \multicolumn{9}{c}{ Cage models } & & \\
\cline { 2 - 5 } & S5 & S6 & F7 & F15 & SEM & $P$-value \\
Number of hens & 15 & 15 & 23 & 23 & & \\
\hline Elastic strain (mm) & 0.96 & 0.91 & 0.88 & 0.85 & 0.04 & 0.78 \\
Bioyield point (N) & 89.1 & 93.2 & 87.6 & 92.8 & 2.9 & 0.87 \\
Stiffness (N per mm) & 98.8 & 115.2 & 113.4 & 118.4 & 3.8 & 0.34 \\
Breaking strength (N) & 137.8 & 152.7 & 150.8 & 155.0 & 3.7 & 0.44 \\
\hline
\end{tabular}

${ }^{1}$ One way ANOVA.

Table III. Mean values for humeral weights and composition in the 72 week-old laying hen in different cage models.

\begin{tabular}{lcccccc}
\hline & \multicolumn{7}{c}{ Cage models } & & \\
\cline { 2 - 5 } Number of hens & S5 & S6 & F7 & F15 & SEM & $P$-value \\
\hline Hydrated weight (g) & 15 & 15 & 23 & 23 & & \\
Dry weight (g) & 48.8 & 54.5 & 50.0 & 49.7 & 0.86 & 0.15 \\
Dry matter (\%) & 29.6 & 32.4 & 30.5 & 30.1 & 0.52 & 0.32 \\
Ash percentage (\%) & 60.7 & 59.8 & 61.3 & 60.7 & 0.39 & 0.67 \\
\hline
\end{tabular}

1 One way ANOVA, mean values labelled with the same letter do not differ significantly (PLSD Fisher test, $P<0.05)$.

matter (Tab. III). The ash percentage was significantly lower in the S6 birds compared to the other cage models (Tab. III).

\section{DISCUSSION}

All the results but one were comparable for standard and furnished cages in our experimental conditions. Thus the parameters related to humeral morphology and quality were not significantly different between the cage models, except in hens reared in one model of the standard cage (S6) in which there was a reduced ash percentage compared to the other cage models. Corticosteroids have well known osteoporotic effects, however, the relationship between stress, blood corticosterone and bone quality remains unclear in birds [7, 44]. This reduction in ash content in S6 cannot be related to an increase in corticosterone level since basal levels did not differ between the cage models. The lower ash percentage for S6 could be due to the higher mortality rate with this cage model, possibly due to the excessively high ambient temperature during the summer months (up to $30^{\circ} \mathrm{C}$ in the building) [20]. The heat dissipation was limited in standard cages, especially with 6 hens per cage, and may have had metabolic consequences on the hens and reduction of mineral feed intake (not measured in our experiment). Reduced ash percentage and mortality rate might have been related to clinical or sub-clinical osteoporosis but this cannot be confirmed since no other observations such as broken bones corroborated this hypothesis. Because only one type of standard cage resulted in a reduction in ash 
content, the lack of enrichment cannot by itself explain this reduction. The higher number of birds in addition to the lack of enrichment may also have contributed to a possible reduction in wing movement: a low number of birds in a cage is more effective in increasing wing movement than the types of cage used [6]. Changes in bone quality are closely related to the patterns of behaviour that are modified since they induce various mechanical strains [43]. Perchery systems have been shown to increase wing flapping and thus to considerably improve breaking strength in the humerus, while terrace systems with ramps from one tier to another increase stepping and breaking strength in the tibiotarsus [27]. In our experimental conditions, the changes in behaviour induced by the furnished cages were possibly too small to enhance bone composition or biomechanical characteristics.

The reason why the decreased ash percentage did not modify the biomechanical characteristics can be explained by the wide range of parameters involved in the flexion test. The flexion curve is dependent on bone composition as well as on bone size (outer and inner dimensions). In the present experiment, the difference in ash percentage appears to have been too slight to induce changes in stiffness or breaking strength, since the bone dimensions may vary in a different way between cage models and counteract the effect of the composition. In the present experiment, we were expecting differences because the perching rate was high (almost $100 \%$ at night, Guesdon unpublished data) in both furnished cage models and the humerus has been reported to be stronger in cages with perches [1]. The fact that biomechanical properties of the humeri were not different between cage models could be due to an insufficient power of the statistical analyses. Because intra-group variability was higher than expected, the tests were also less powerful than expected. However, with our data, an average $1.22 \%$ difference can be detected with a sample number of 15 and an average $0.98 \%$ differ- ence can be detected with a sample number of 23. These percentages can be observed in the various parameters we studied. We can then assume that the non-existence of the differences between cage models appears to be related to the fact that furnished and standard cages may be considered as very similar systems when compared to aviaries in which more space is available for movement and flying. In some cases, although low stocking densities were used $\left(3045 \mathrm{~cm}^{2}\right.$ per bird including the nest box compared to $1524 \mathrm{~cm}^{2}$ per bird), the furnished cages used did not allow the hens to perform wing flapping [4]. In battery-caged birds, the strength and the radiographic density of the humerus were lowered by 40 to $50 \%$ compared to data obtained in various aviary systems [17]. When Wilson et al. [53] compared cages with and without perches, they noticed a difference in the trabecular bone but they also noticed that osteopenia was widespread in both types of cages, suggesting that other factors must be studied to improve bone quality in laying hens since the enrichment of cages was not effective enough to achieve this.

Furnished cages were also not effective in modifying adrenal responsiveness whereas a bare environment has been reported to induce chronic stress [12, 24]. Moreover adrenal reactivity has been shown to differ in ducks raised in different rearing conditions (collective vs. individual cages), making it possible to conclude upon a chronically stressful environment [19]. In the present experimental conditions, it was only feasible to measure basal levels and to investigate maximal adrenal reactivity since the birds had to be removed from their cage in order to be injected and bled. The results from our laboratory and those from the literature indicate that a single measurement of plasma corticosterone taken 15 minutes post-injection of a dose of $10 \mu \mathrm{g}$ per hen or higher can be used to test full adrenal gland reactivity. Under our present experimental conditions, we did not observe any difference in corticosterone changes that could 
have indicated differing states of adrenal reactivity related to a different stress status.

We conclude that furnished cages were not effective in improving humeral quality, possibly because frequent wing movements cannot be performed in these rearing conditions. The present results concerning the investigation of HPA reactivity also gave no indication that these cages were perceived as less stressful than standard cages by the hens.

\section{ACNOWLEDGEMENTS}

This project was supported financially by the CNPO (Centre National pour la Promotion de l'Oeuf), the DGAL (Direction Générale de l'Alimentation) and the OFIVAL (Office National Interprofessionnel des Viandes de l'Élevage et de l'Aviculture). We thank Dr. R.J. Etches (University of Guelph, Canada) for supplying the materials used in the corticosterone assays and Mrs. Maryse Garreau-Mills and Mrs. Nathaële Wacrenier for expert technical assistance and all the workers from the SRA experimental unit for care of the birds.

\section{REFERENCES}

[1] Abrahamsson P., Tauson R., Effect of perches at different positions in conventional cages for laying hens of two different strains, Acta Agric. Scand. A-An. 43 (1993) 228-235.

[2] Abrahamsson P., Tauson R., Aviary systems and conventional cages for laying hens. Effects on production, egg quality, health and bird location in three hybrids, Acta Agric. Scand. A-An. 45 (1995) 191-203.

[3] Abrahamsson P., Tauson R., Appleby M.C., Behaviour, health and integument of four hybrids of laying hens in modified and conventional cages, Brit. Poult. Sci. 37 (1996) 521-540.

[4] Albentosa M.J., Cooper J.J., Cage height preferences of groups of hens housed in furnished cages, Brit. Poult. Sci. 44 (Suppl. 1) (2003) S5-S6.

[5] Appleby M.C., Hughes B.O., Welfare of laying hens in cages and alternative systems: environmental, physical and behavioural aspects, World Poult. Sci. J. 47 (1991) 109_ 128.

[6] Appleby M.C., Walker A.W., Nicol C.J., Lindberg A.C., Freire R., Hughes B.O., Elson H.A., Development of furnished cages for laying hens, Brit. Poult. Sci. 43 (2002) 489-500.

[7] Barnett J.L., Glatz P.C., Newman E.A., Cronin G.M., Effects of modifying layer cages with solid sides on stress physiology, plumage, pecking and bone strength of hens, Aust. J. Exp. Agric. 37 (1997) 11-18.

[8] Baxter M.R., The welfare problems of laying hens in battery cages, Vet. Rec. 134 (1994) 614-619.

[9] Beuving G., Vonder G.M., Effect of stressing factors on corticosterone levels in plasma of laying hens, Gen. Comp. Endocrinol. 35 (1978) 153-159.

[10] CEC, Council Directive 99/74/EC: laying down minimum standards for protection of laying hens, Official Journal of the European of the European Communities (L 203/53) 19 July, 1999, pp. 53-57.

[11] Collet P., Uebelhart D., Vico L., Moro L., Hartmann D., Roth M., Alexandre C., Effects of 1- and 6-month spaceflight on bone mass and biochemistry in two humans, Bone 20 (1997) 547-551.

[12] Dantzer R., Mormede P., Le stress en élevage intensif, in: Masson (Ed.), Paris, France, 1979, p. 118.

[13] Davicco M.J., Horcajada-Molteni M.N., Gaumet-Meunier N., Lebecque P., Coxam V., Barlet J.P., Endurance training and bone metabolism in middle-aged rats, Mech. Ageing Dev. 109 (1999) 83-96.

[14] Destombes N., Guémené D., Faure J.M., Guy G., Physiological ability to respond to an acute stress during the force-feeding period in male mule ducks, Proceedings of the 11th European Symposium on Waterfowl, in: Branche française de la WPSA (Ed.), Nantes, France, 1997, pp. 230-238.

[15] Etches R.J., A radioimmunoassay for corticosterone and its application to the measurement of stress in poultry, Steroids 28 (1976) $763-773$.

[16] Faure J.M., Besoin en espace chez la poule pondeuse, in: Picard M., Porter R.H., Signoret J.P. (Eds.), Comportement et bien-être animal, Paris, France, 1994, pp. 161-167.

[17] Fleming R.H., Whitehead C.C., Alvey D., Gregory N.G., Wilkins L.J., Bone structure and breaking strength in laying hens housed in 
different husbandry systems, Brit. Poult. Sci. 35 (1994) 651-662.

[18] Freeman B.M., Stress and the domestic fowl: a physiological reappraisal, World Poult. Sci. J. 27 (1976) 263-275

[19] Guémené D., Guy G., Noirault J., Destombes N., Samson M., Gouraud P., Garreau-Mills M., Faure J.M., Physiological and behavioural responses to force-feeding procedure in male mule ducks and ganders, Proceedings of the 1th World Waterfowl Conference, in: Branche française de la WPSA (Ed.), Taichung, Taïwan, 1999, pp. 413-424.

[20] Guesdon V., Faure J.M., Laying performances and egg quality in hens kept in standard or furnished cages, Anim. Res. 53 (2004) 4557.

[21] Harvey S., Merry B.J., Phillips J.G., Influence of stress on the secretion of corticosterone in the duck (Anas platyrhynchos), J. Endocrinol. 87 (1980) 161-171.

[22] Hirano T., Burr D.B., Turner C.H., Sato M., Cain R.L., Hock J.M., Anabolic effects of human biosynthetic parathyroid hormone fragment (1-34), LY333334, on remodeling and mechanical properties of cortical bone in rabbits, J. Bone Miner. Res. 14 (1999) 536545.

[23] Hughes B.O., Wilson S., Appleby M.C., Smith S.F., Comparison of bone volume and strength as measures of skeletal integrity in caged laying hens with access to perches, Res. Vet. Sci. 54 (1993) 202-206.

[24] Janssens C.J., Helmond F.A., Wiegant V.M., Increased cortisol response to exogenous adrenocorticotropic hormone in chronically stressed pigs: influence of housing conditions, J. Anim. Sci. 72 (1994) 1771-1777.

[25] Jones R.B., Faure J.M., The effects of regular handling on fear responses in the domestic chick, Behav. Process. 6 (1981) 135-143.

[26] Kettlewell P.J., Mitchell M.A., Catching, handling and loading of poultry for road transportation, World Poult. Sci. J. 50 (1994) 54-56.

[27] Knowles T.G., Broom D.M., Limb bone strength and movement in laying hens from different housing systems, Vet. Rec. 126 (1990) 354-356.

[28] Koelkebeck K.W., Cain J.R., Amoss M.S. Jr., Use of adrenocorticotropin challenges to indicate chronic stress responses of laying hens in several housing alternatives, Domest. Anim. Endocrinol. 3 (1986) 301-305.
[29] Kuit A.R., Ehlhardt D.A., Blokuis H.J., Alternative improved housing systems for poultry, Commission of the European Communities, Beekbergen, The Netherlands, 1989, p. 163

[30] Landsberg J.W., Weiss J., Stress and increase of the corticosterone level prevent imprinting in ducklings, Behaviour 57 (1976) 173-189.

[31] McCoy M.A., Reilly G.A., Kilpatrick D.J., Density and breaking strength and bones of mortalities among caged layers, Res. Vet. Sci. 60 (1996) 185-186.

[32] Meyer W.A., Sunde M.L., Bone breakage as affected by type housing or an exercise machine for layers, Poult. Sci. (1974) 878885 .

[33] Michel V., Huonnic D., Protais J., Cotte J.P., Comparaison du bien-être, de l'état de sanitaire et des performances zootechniques de poules pondeuses, élevées dans un système classique de cages ou dans un système alternatif de type « volière » : résultats préliminaires, Compte rendu $5^{\text {es }}$ Journées de la Recherche Avicole, in: Branche française de la WPSA (Ed.), Tours, France, 2003, pp. 69-76.

[34] Mills A.D., Wood-Gush D.G.M., Pre-laying behaviour in battery cages, Brit. Poult. Sci. 26 (1985) 247-252.

[35] Mitchell M.A., Kettlewell P.J., Maxwell M.H., Indicators of physiological stress in broiler chickens during road transportation, Anim. Welfare 1 (1992) 91-103.

[36] Moinard C., Morisse J.P., Faure J.M., Effect of cage area, cage height and perches on feather condition, bone breakage and mortality of laying hens, Brit. Poult. Sci. 39 (1998) 198-202.

[37] Nicol C.J., A study of the behavioural needs of battery housed hen, Oxford University, Oxford, UK, 1986, p. 445.

[38] Nicol C.J., Effect of cage height and area on the behaviour of hens housed in battery cages, Brit. Poult. Sci. 28 (1987) 327-335.

[39] Nicol C.J., Behavioural responses of laying hens following a period of spatial restriction, Anim. Behav. 35 (1987) 1709-1719.

[40] Noirault J., Guémené D., Guy G., Faure J.M., Corticosterone plasma concentration in male mule ducks: effects of sampling sites, repeated samplings and ACTH injections, Brit. Poult. Sci. 40 (1999) 304-308.

[41] Norgaard-Nielsen G., Bone strength of laying hens kept in an alternative system compared with hens in cages and on deep-litter, Brit. Poult. Sci. 31 (1990) 81-89. 
[42] Reiter K., Bessei W., Effect of locomotor activity on bone development and leg disorders in broilers, Einfluss der Laufaktivität auf die Knochenentwicklung und Beinshäden bei Broilern, Arch. Geflügelkd. 62 (1998) 247253.

[43] Rubin C.T., Lanyon L.E., Regulation of bone mass by mechanical strain magnitude, Calcif. Tissue Int. 37 (1985) 411-417.

[44] Satterlee D.G., Roberts E.D., The influence of stress treatment on femur cortical bone porosity and medullary bone status in Japanese quail selected for high and low blood corticosterone response to stress, Comp. Biochem. Phys. A 95 (1990) 401-405.

[45] Siegel H.S., Adrenals, stress and the environment, World Poult. Sci. J. 27 (1971) 327-349.

[46] Tanaka T., Hurnik J.F., Comparison of behavior and performance of laying hens housed in battery cages and an aviary, Poult. Sci. 71 (1992) 235-243.

[47] Tanaka T., Hurnik J.F., Stereotyped behavior in caged laying hens, Anim. Sci. Tech. 63 (1992) 800-804.

[48] Taylor A.A., Hurnik J.F., The effect of longterm housing in an aviary and battery cages on the physical condition of laying hens: body weight, feather condition, claw length, foot lesions, and tibia strength, Poult. Sci. 73 (1994) 268-273.

[49] Thorn G.W., Jenkins D., Laidlaw J.C., Goetz F.C., Dingman J.F., Arons W.L., Streeten D.H.P., Medical progress: pharmacologic aspects of adrenocortical steroids and ACTH in man, New England J. Med. (1953) 232248 .

[50] Vestergaard K.S., Skadhauge E., Lawson L.G., The stress of not being able to perform dustbathing in laying hens, Physiol. Behav. 62 (1997) 413-419.

[51] Vico L., Pouget J.F., Calmels P., Chatard J.C., Rehailia M., Minaire P., Geyssant A., Alexandre C., The relations between physical ability and bone mass in women aged over 65 years, $\mathrm{J}$. Bone Miner. Res. 10 (1995) 374-383.

[52] Vitorovic D., Nikolic Z., Cvetkovic D., In vivo tetracycline labelling as a measure of rearing-system influence on chicken-bone dynamics, Anat. Histol. Embryol. 24 (1995) 85-86.

[53] Wilson S., Hughes B.O., Appleby M.C., Smith S.F., Effects of perches on trabecular bone volume in laying hens, Res. Vet. Sci. 54 (1993) 207-211. 